\title{
Pengenalan Objek Bunga dengan Ekstraksi Fitur Warna dan Bentuk Menggunakan Metode Morfologi dan Naïve Bayes
}

\author{
Maulana Fansyuri ${ }^{1}$, Oke Hariansyah ${ }^{2}$ \\ Universitas Pamulang \\ e-mail: 1'dosen02359@unpam.ac.id, 2dosen00840@unpam.ac.id \\ Diajukan: 6 September 2020; Direvisi: 25 November 2020; Diterima: 30 November 2020
}

\begin{abstract}
Abstrak
Pengenalan objek pada citra digital mendapat banyak perhatian dalam beberapa tahun terakhir ini. Hal ini terlihat dari penerapan identifikasi citra di beberapa bidang kerja seperti pengenalan gambar untuk perencanaan lahan pertanian, identifikasi penyakit tanaman dan pencitraan medis. Teknik pengolahan gambar juga banyak digunakan oleh ahli botani dalam mengidentifikasi spesies tanaman yang tidak diketahui. Metode yang di terapkan di dalam penelitian ini untuk masalah proses pengenalan citra bunga adalah Ekstraksi model warna dan ekstraksi fitur bentuk untuk menaikkan tingkat akurasi dalam pengenalan citra bunga. Hasil ekstraksi warna dan bentuk bunga tersebut diklasifikasikan menggunakan metode Nä̈ve Bayes dengan tujuan agar bisa mendapatkan tingkat akurasi terbaik dalam proses klasifikasi citra bunga. Penelitian ini menggunakan 285 data citra bunga yang merupakan data set dari 19 spesies bunga yang berbeda, dataset dalam penelitian ini dibagi menjadi dua bagian, yaitu 228 data tes dan 57 data training. Hasil dari ekstraksi fitur dan warna menggunakan metode Morfologi dan Nä̈ve Bayes ini dilakukan pengujian akurasi menggunakan metode Confusion Matrix, menghasilkan tingkat akurasi sebesar 71,1\% dengan kategori klasifikasi yang baik.
\end{abstract}

Kata kunci: Pengenalan, Klasifikasi, Nä̈ve Bayes, Confusion Matrix.

\begin{abstract}
The introduction of objects in digital images has received a lot of attention in recent years. This can be seen from the application of image identification in several fields of work such as image recognition for agricultural land planning, identification of plant diseases and medical imaging. Image processing techniques are also widely used by botanists in identifying unknown plant species. The method applied in this research for the problem of the flower image recognition process is the extraction of the color model and the extraction of shape features to increase the level of accuracy in the recognition of flower images. The results of the color and flower shape extraction are classified using the Nä̈ve Bayes method in order to get the best level of accuracy in the flower image classification process. This study uses 285 flower image data which is a data set of 19 different flower species. The dataset in this study is divided into two parts, namely 228 test data and 57 training data. The results of the feature and color extraction using the Morphology and Nä̈ve Bayes methods were accuracy tested using the Confusion Matrix method, resulting in an accuracy rate of $71.1 \%$ with a good classification category.
\end{abstract}

Keywords: Recognition, Classification, Nä̈ve Bayes, Confusion Matrix.

\section{Pendahuluan}

Pengenalan objek pada citra digital menjadi bidang ilmu yang banyak diteliti akhir-akhir ini. Hal ini terlihat dari penerapan di beberapa bisa seperti pengenalan gambar untuk perencanaan lahan pertanian [1][2], pengenalan citra wajah [3], dan pencitraan medis[4]. Teknik pengolahan gambar juga banyak digunakan oleh ahli botani dalam mengidentifikasi spesies tanaman yang tidak diketahui. Meskipun daun sangat penting di dalam proses pengenalan tanaman, bagian lain seperti bunga dapat mendukung proses pengenalan tersebut [5].

Klasifikasi bunga dalam proses pengenalan citra bunga adalah proses yang cukup menantang seperti yang ditunjukkan oleh penelitian Rosyani, dkk [5]. Di dalam penelitiannya mengombinasikan fitur warna RGB, HSV, LAB, dan YCBCR dengan kombinasi segmentasi K-Means dan klasifikasi SVM untuk mendapatkan tingkat akurasi yang baik. Sistem pengenalan bunga juga diteliti oleh Apriyanti, dkk [6] yang meneliti tentang Bunga Anggrek. 
Di dalam proses klasifikasi hal yang perlu dilakukan sebelumnya adalah mengambil fitur-fitur yang dibutuhkan seperti fitur bentuk dan warna pada bunga. Pengambilan fitur ini dilakukan untuk mengambil daerah penting daerah penting ini adalah memisahkan objek dengan background pada citra, dibutuhkan proses pengambilan fitur atau ekstraksi fitur. Untuk mengetahui data dari suatu citra, diperlukan metode ekstraksi ciri. Ekstraksi ciri merupakan metode dalam pemrosesan citra dengan mengambil beberapa bagian pada citra yang bisa menunjukkan ciri khas dari citra tersebut, data yang dapat diambil misalnya pola, warna, bentuk, diameter, dan masih banyak lagi. Ekstraksi citra warna yaitu data citra digital yang mempunyai parameter kombinasi data warna red, green, dan blue, sedangkan parameter dihasilkan dari Ekstraksi citra bentuk yaitu eccentricity dan metric.

Penggunaan metode Naïve Bayes sudah banyak diterapkan untuk melakukan klasifikasi data hasil ekstraksi data citra, pada penelitian ini penggunaan metode Naïve Bayes bertujuan untuk bisa mendapatkan tingkat akurasi terbaik dalam proses klasifikasi citra bunga, sehingga memperkuat kesesuaian data hasil pengolahan citra dengan data sebenarnya. Penerapan metode Naïve Bayes sudah pernah dilakukan untuk mengklasifikasikan citra buah belimbing, dengan metode ini tingkat akurasi yang didapatkan sebesar $80 \%$ [7]. Dari hasil tersebut, peneliti tertarik menggunakan metode Naïve Bayes untuk menerapkan klasifikasi citra berdasarkan warna dan bentuk pada bunga.

Berdasarkan uraian di atas, maka penelitian ini menganalisis citra bunga di mana kombinasi yang digunakan adalah dari data warna yang terdiri dari fitur HSV dan YCBCR, dan data bentuk yang terdiri dari fitur eccentricity dan metric. Hasil ekstraksi warna dan bentuk tersebut dianalisis menggunakan algoritma Naïve Bayes sehingga keakuratan data ekstraksi dengan data sebenarnya lebih optimal. Penelitian ini dapat digunakan oleh ahli botani atau petani untuk mendapatkan teori dan produksi bunga yang lebih baik.

\section{Metode Penelitian}

Metode dalam penelitian ini dilakukan dalam dua fase, yaitu fase pelatihan dan fase pengujian. Dalam fase pelatihan, tahapan yang dilakukan bertujuan untuk mendapatkan model berdasarkan subset citra yang disebut citra latih [8]. Ada beberapa tahapan dalam proses Analisis citra bunga berdasarkan warna dan bentuk, tahapan tersebut termuat dalam diagram alur seperti di bawah ini:

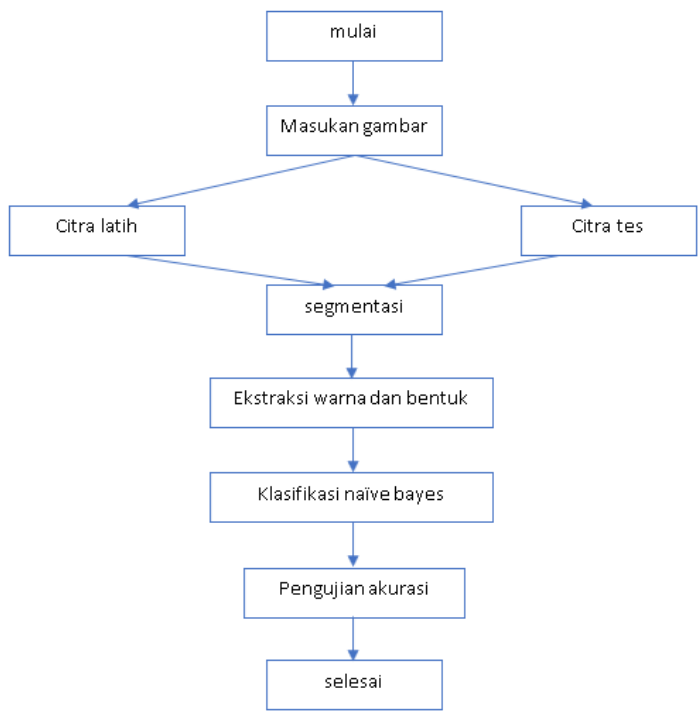

Gambar 1. Metode penelitian.

Berikut penjelasan dari tahapan metode penelitian yang dilakukan:

1. Langkah pertama adalah menyiapkan data set gambar yang akan dianalisis. Dataset gambar yang digunakan adalah 19 gambar bunga dari dataset ImageClef2018 dan melakukan pengambilan gambar sebanyak 285 kali. Gambar bunga yang diambil tersebut memiliki background yang kompleks sehingga untuk proses selanjutnya harus memisahkan background dan objek (foreground) dari gambar tersebut.

2. Dari 285 dataset ini kemudian dibagi menjadi 2 bagian yaitu $80 \%$ akan digunakan sebagai data tes yaitu sebanyak 228 data citra dan $20 \%$ akan digunakan sebagai data latih yaitu sebanyak 57 data citra.

Pengenalan Objek Bunga dengan Ekstraksi Fitur Warna dan Bentuk Menggunakan Metode Morfologi dan Nä̈ve Bayes (Maulana Fansyuri) 
3. Dari setiap gambar latih dan tes tersebut akan dilakukan segmentasi untuk memisahkan objek (foreground) dan background menggunakan metode K-Means Clustering. Tahapan proses segmentasi menggunakan metode ini yaitu [9].

a. Membaca citra asli

b. Mengonversi RGB dari citra tersebut menjadi grayscale

c. Melakukan segmentasi citra menggunakan algoritma K-Means Clustering yang bertujuan untuk membagi dua region cluster yaitu kluster 1 untuk region berwarna hitam yang menunjukkan background data gambar tersebut dan kluster 2 untuk region berwarna kuning yang menunjukkan objek (foreground) dari gambar tersebut.

d. Memilih region kluster yang memiliki luas paling kecil untuk menunjukkan bahwa region tersebut adalah objek (foreground) dari data yang akan diolah.

e. Melakukan proses filtering dengan menggunakan median filter pada citra tersebut.

f. Melakukan proses operasi morfologi dengan tujuan untuk menghilangkan noise pada hasil filtering sehingga mendapatkan hasil segmentasi yang lebih akurat.

g. Mendapatkan data citra biner hasil operasi morfologi tersebut

4. Setelah data citra biner didapatkan dari hasil segmentasi, proses selanjutnya adalah melakukan ekstraksi warna dan bentuk dari data tersebut, di mana data yang diambil dari fitur warna adalah data rata-rata dari HSV dan data rata-rata dari YCBCR, serta fitur bentuk yang diambil adalah dari eccentricity dan metric.

5. Langkah selanjutnya adalah penerapan metode Naïve Bayes dari data fitur warna dan bentuk yang telah didapat. Tahapan proses metode Naïve Bayes ini yaitu [7]:

a. Menghitung nilai probabilitas (prior) dari setiap variabel dari data tes yang didapat dari hasil ekstraksi citra.

b. Karena data hasil Ekstraksi citra merupakan data numerik, maka langkah selanjutnya adalah mencari nilai rata-rata (mean) dari setiap variable dengan persamaan:

$$
\mu=\sum_{i=1}^{n} x i
$$

c. Kemudian menghitung standar deviasi dari setiap variabel tersebut dengan persamaan.

$$
\text { Ó= } \sqrt{\sum_{i=1}^{n} \frac{(\mathrm{xi}-\mu)^{2}}{2}}
$$

d. Kemudian menghitung Densitas probabilitas dari setiap jenis spesies citra bunga dengan mengambil sampel dari data citra latih untuk menentukan keakuratan data berdasarkan data tes yang sudah diolah dengan persamaan:

$$
p(x=v \mid c)=\frac{1}{\sqrt{2 \mu \hat{O}^{2}}} \exp ^{\frac{(\mathrm{x}-\mu)^{2}}{2 \hat{O}^{2}}}
$$

e. Probabilitas yang dihasilkan dari perhitungan densitas probabilitas dan memiliki nilai paling besar akan menunjukkan spesies dari citra tersebut.

f. Setelah dilakukan pengolahan data menggunakan algoritma Naïve Bayes, akan didapatkan nilai akurasi data hasil ekstraksi dengan data citra bunga sebenarnya.

\subsection{Data Citra Collection}

Dataset yang digunakan terdiri dari 19 jenis spesies citra bunga dan masing-masing spesies memiliki 15 citra bunga sehingga total data citra yang digunakan sebagai dataset berjumlah 285 data. Dari seluruh dataset ini kemudian dibagi menjadi 2 bagian yaitu $80 \%$ akan digunakan sebagai data tes yaitu sebanyak 228 data citra dan $20 \%$ akan digunakan sebagai data latih yaitu sebanyak 57 data citra. 


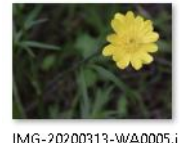

pg

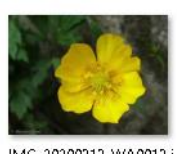

IMG-20200313-

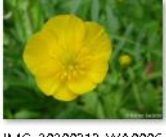

pg

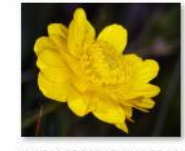

IMG-20200313

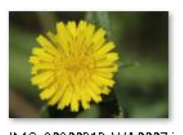

IMG-20200313

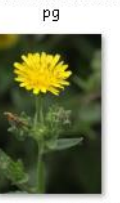

IMG-2020031

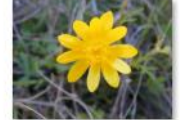

Lusastak $\mathrm{pg}$

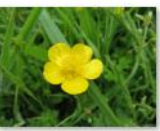

IMG-20200313-WA0017.

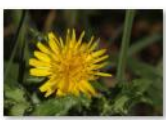

Co dista pg

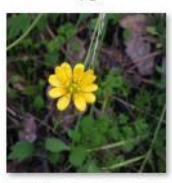

IMG-20200313-WA0018j

$\mathrm{pg}$

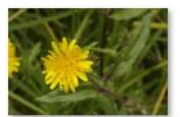

IMG-20200313-WA0010j

$\mathrm{pg}$

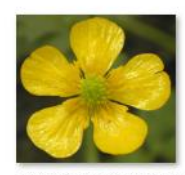

IMG-20200313

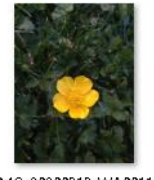

pg

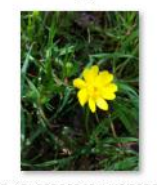

$\mathrm{pg}$

Gambar 2. Contoh dataset.

\subsection{Image Data Pre-Processing}

Pada tahapan ini merupakan tahap segmentasi citra menggunakan metode K-Means Clustering, pada segmentasi ini dilakukan menggunakan aplikasi MATLAB untuk dapat melakukan ekstraksi citra bunga menjadi data citra biner yang dapat menghasilkan ekstraksi warna dan bentuk. Tahap awal dalam segmentasi ini yaitu membagi citra bunga menjadi dua region cluster yaitu cluster hitam yang menunjukkan background dan cluster kuning yang menunjukkan objek atau foreground.

Selanjutnya memilih region kluster yang paling luas pada gambar yang menunjukkan bahwa region tersebut adalah objek atau foreground, sehingga hasil seleksi ini dapat diolah di langkah selanjutnya. Setelah melakukan seleksi objek, langkah selanjutnya adalah melakukan proses filtering dengan menggunakan median filter pada citra. Selanjutnya adalah melakukan proses morfologi yang bertujuan untuk menghilangkan noise pada gambar yang sudah di filter sehingga dapat memberikan hasil segmentasi yang lebih akurat. Tahap akhir dari segmentasi ini adalah mendapatkan data citra biner dari hasil operasi morfologi citra .

\subsection{Citra Training}

Citra training merupakan data hasil segmentasi menggunakan metode K-Means Clustering dan ekstraksi citra. Data ini berisi fitur warna yang terdiri dari nilai Mean $\mathrm{H}$, Mean $\mathrm{S}$, Mean V, Mean Y, Mean $\mathrm{CB}$, Mean $\mathrm{CR}$, dan fitur bentuk dari citra bunga yang terdiri dari eccentricity dan metric.

\subsection{Metode Naïve Bayes}

Naïve Bayes merupakan algoritma klasifikasi yang sederhana di mana setiap atribut bersifat independen dan memungkinkan berkontribusi terhadap keputusan akhir. Naïve Bayes merupakan pengklasifikasian dengan metode probabilitas dan statistik yang dikemukakan oleh ilmuwan Inggris Thomas Bayes, yaitu memprediksi peluang di masa depan berdasarkan pengalaman di masa sebelumnya sehingga dikenal sebagai Teorema Bayes. Persamaan dari Teorema Bayes adalah:

Di mana:

$$
p(H \mid X) \frac{p(H \mid X) \cdot P X}{P(X)}
$$

$X \quad$ : Data dengan class yang belum diketahui

$H \quad$ : Hipotesis data $\mathrm{X}$ merupakan suatu class spesifik

$P(H \mid X) \quad$ : Probabilitas hipotesis $\mathrm{H}$ berdasar kondisi X (posterior probability)

$P(H) \quad$ : Probabilitas hipotesis $\mathrm{H}$ (prior probability)

$P(X \mid H)$ : Probabilitas X berdasarkan kondisi pada hipotesis $\mathrm{H}$

$P(X) \quad$ : Probabilitas $\mathrm{X}$

Untuk menjelaskan teorema Naive Bayes, perlu diketahui bahwa proses klasifikasi memerlukan sejumlah petunjuk untuk menentukan kelas apa yang cocok bagi sampel yang dianalisis tersebut. Karena itu, teorema Bayes di atas disesuaikan sebagai berikut:

$$
P(C \mid F 1 \ldots F n) \frac{P(C) \cdot P(F 1 \ldots F n \mid C)}{P(F 1 \ldots F n)}
$$


Di mana variabel C mempresentasikan kelas, sementara variabel (F1...Fn) mempresentasikan karakteristik petunjuk yang dibutuhkan untuk melakukan klasifikasi. Maka rumus tersebut menjelaskan bahwa peluang masuknya sampel karakteristik tertentu dalam kelas $\mathrm{C}$ (Posterior) adalah peluang munculnya kelas $\mathrm{C}$ (sebelum masuknya sampel tersebut, sering kali disebut prior), dikali dengan peluang kemunculan karakteristik-karakteristik sampel pada kelas C (disebut juga likelihood), dibagi dengan peluang kemunculan karakteristik-karakteristik sampel secara global (disebut juga evidence).

Adapun alur dari metode Naïve Bayes adalah sebagai berikut:

1. Input data

2. Training baca data training.

3. Hitung jumlah dan probabilitas, namun apabila data numerik maka:

a. Cari nilai mean dan standar deviasi dari masing-masing parameter yang merupakan data numerik.

b. Cari nilai probabilistik dengan cara menghitung jumlah data yang sesuai dari kategori yang sama dibagi dengan jumlah data pada kategori tersebut.

4. Mendapatkan nilai dalam tabel mean, standar deviasi, dan probabilitas.

\section{Hasil dan Pembahasan}

Ada beberapa tahapan dalam proses Analisis citra bunga berdasarkan warna dan bentuk yang dilakukan dalam penelitian ini.

\subsection{Persiapan Gambar}

Data set yang digunakan terdiri dari 19 jenis spesies citra bunga dan masing-masing spesies memiliki 15 citra bunga sehingga total data citra yang digunakan sebagai dataset berjumlah 285 gambar.

\subsection{Pembagian Dataset}

Dari seluruh dataset ini kemudian dibagi menjadi 2 bagian yaitu $80 \%$ akan digunakan sebagai data latih yaitu sebanyak 228 data citra dan $20 \%$ akan digunakan sebagai data tes yaitu sebanyak 57 data citra.

\subsection{Proses Segmentasi}

Tahap awal segmentasi ini dilakukan pada fase pelatihan yaitu tahapan yang dilakukan bertujuan untuk mendapatkan model berdasarkan citra latih. Tahap segmentasi citra menggunakan metode K-Means Clustering, pada segmentasi ini dilakukan menggunakan aplikasi MATLAB untuk dapat melakukan ekstraksi citra bunga menjadi data citra biner yang dapat menghasilkan ekstraksi warna dan bentuk. Proses awal segmentasi ini diterapkan pada data tes, yaitu citra bunga sebanyak 57 data.

Selanjutnya preprocessing, yaitu melakukan operator-operator seperti konversi, holes filling, open area. pemilihan bunga jika ada bunga yang lebih dari satu, untuk case gambar bunga lebih dari satu diperlukan metode khusus seperti merging untuk memisahkan bunga agar hanya terdapat 1 bunga saja di dalam frame.

Setelah tampil 1 bunga dalam frame, selanjutnya membagi citra bunga menjadi dua region cluster yaitu cluster hitam yang menunjukkan background dan cluster kuning yang menunjukkan objek atau foreground.

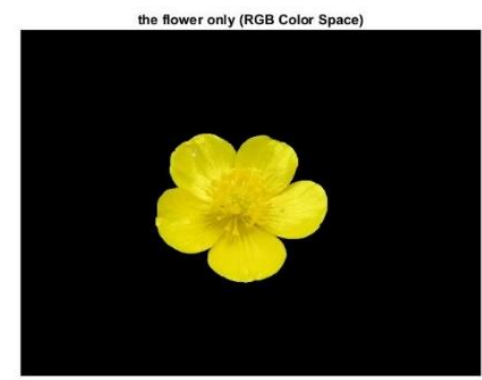

Gambar 3. Contoh gambar hasil segmentasi citra.

\subsection{Ekstraksi Warna dan Bentuk}

Selanjutnya adalah melakukan proses ekstraksi warna dan bentuk menggunakan metode morfologi yang bertujuan untuk menghilangkan noise pada gambar yang sudah di filter sehingga dapat memberikan hasil segmentasi yang lebih akurat. Tahap akhir dari segmentasi ini adalah mendapatkan data citra biner dari hasil operasi morfologi citra. 
Hasil dari ekstraksi citra, selanjutnya dibuat data citra training yang merupakan data hasil segmentasi menggunakan metode K-Means Clustering dan ekstraksi citra yang telah disederhanakan agar proses Analisis menggunakan metode Naïve Bayes lebih terfokus. Data ini berisi fitur warna yang terdiri dari nilai Mean $\mathrm{H}$, Mean S, Mean V, Mean Y, Mean $\mathrm{CB}$, Mean $\mathrm{CR}$, dan fitur bentuk dari citra bunga yang terdiri dari eccentricity dan metric.

Setelah selesai proses ekstraksi warna dan bentuk menggunakan data tes, selanjutnya adalah fase pengujian, yaitu tahapan yang dilakukan bertujuan untuk mendapatkan model berdasarkan citra tes. Data yang diproses berjumlah 228 data citra. Proses yang dilakukan sama seperti yang diterapkan pada data tes, yaitu proses segmentasi hingga ekstraksi warna dan bentuk.

\subsection{Klasifikasi Naïve Bayes}

Variabel yang digunakan dalam perhitungan Naïve Bayes menggunakan fitur warna yang terdiri dari Mean $\mathrm{H}$, Mean S, Mean $\mathrm{V}$, Mean Y, Mean CB, Mean CR, dan fitur bentuk yang terdiri dari eccentricity dan metric yang merupakan hasil ekstraksi citra bunga. Data ekstraksi citra hasil data fase pelatihan dan fase pengujian yang berjumlah 228 untuk data tes dan 57 untuk data latih.

Tabel 1. Contoh data latih.

\begin{tabular}{|c|c|c|c|c|c|c|c|c|}
\hline \multirow{2}{*}{ Spesies } & \multicolumn{3}{|c|}{ HSV MEAN } & \multicolumn{2}{|c|}{ Pola - eccentricity } & \multicolumn{3}{|c|}{ Y CB CR MEAN } \\
\hline & H_mean & S_mean & V_mean & eccentricity & metric & Y_mean & Cb_mean & Cr_mean \\
\hline Brodiaea elegans Hoover & 0,708 & 0,469 & 0,754 & 0,253 & 0,294 & 122,820 & 160,732 & 137,507 \\
\hline Brodiaea elegans Hoover & 0,724 & 0,447 & 0,799 & 0,100 & 0,185 & 134,956 & 158,640 & 143,362 \\
\hline Brodiaea elegans Hoover & 0,783 & 0,469 & 0,693 & 0,363 & 0,175 & 128,662 & 148,404 & 152,961 \\
\hline Calochortus kennedyi Porter & 0,046 & 0,871 & 0,800 & 0,323 & 0,788 & 107,410 & 88,677 & 189,190 \\
\hline Calochortus kennedyi Porter & 0,166 & 0,840 & 0,391 & 0,414 & 0,873 & 50,415 & 112,742 & 165,174 \\
\hline Calochortus kennedyi Porter & 0,084 & 0,825 & 0,846 & 0,628 & 0,702 & 139,637 & 73,152 & 172,926 \\
\hline Calochortus luteus Douglas ex & 0,155 & 0,936 & 0,311 & 0,360 & 0,802 & 73,810 & 96,541 & 135,498 \\
\hline Calochortus luteus Douglas ex & 0,154 & 0,957 & 0,311 & 0,266 & 0,834 & 73,589 & 96,227 & 135,529 \\
\hline Calochortus luteus Douglas ex & 0,155 & 0,946 & 0,359 & 0,480 & 0,622 & 82,914 & 91,622 & 136,484 \\
\hline Calochortus splendens Douglas ex & 0,829 & 0,335 & 0,808 & 0,176 & 0,895 & 157,827 & 147,196 & 151,133 \\
\hline Calochortus splendens Douglas ex & 0,821 & 0,348 & 0,700 & 0,262 & 0,788 & 137,244 & 145,176 & 147,256 \\
\hline Calochortus splendens Douglas ex & 0,811 & 0,534 & 0,659 & 0,450 & 0,680 & 112,617 & 154,659 & 153,910 \\
\hline Dichelostemma congestum (Sm.) Kunth & 0,732 & 0,518 & 0,818 & 0,581 & 0,138 & 127,127 & 167,042 & 139,590 \\
\hline Dichelostemma congestum (Sm.) Kunth & 0,740 & 0,294 & 0,648 & 0,851 & 0,108 & 129,995 & 143,724 & 134,286 \\
\hline Dichelostemma congestum (Sm.) Kunth & 0,742 & 0,345 & 0,549 & 0,437 & 0,196 & 108,422 & 143,494 & 134,512 \\
\hline
\end{tabular}

Selanjutnya menghitung Mean dari setiap variabel menggunakan persamaan:

$$
\mu=\sum_{i=1}^{n} x i
$$

Menghitung nilai mean dari data latih yaitu menghitung rata-rata dari setiap spesies data bunga, misal untuk data spesies Brodiaea elegans Hoover memiliki nilai Hue yaitu: 0,708, 0,724 dan 0,783. Maka rata-rata dari nilai Hue tersebut adalah 0,738. Hasil perhitungan Mean seluruh data latih terlihat pada tabel di bawah ini:

Tabel 2. Mean

\begin{tabular}{lcccccccc}
\hline \multicolumn{1}{c}{ Mean } & H & S & V & Eccentricity & Metric & Y & CB & CR \\
\hline Brodiaea elegans Hoover & 0,738 & 0,462 & 0,749 & 0,239 & 0,218 & 128,813 & 155,926 & 144,610 \\
\hline Calochortus kennedyi Porter & 0,099 & 0,845 & 0,679 & 0,455 & 0,788 & 99,154 & 91,524 & 175,763 \\
\hline Calochortus luteus Douglas ex & 0,155 & 0,947 & 0,327 & 0,369 & 0,753 & 76,771 & 94,797 & 135,837 \\
\hline Calochortus splendens Douglas ex & 0,820 & 0,406 & 0,722 & 0,296 & 0,788 & 135,896 & 149,010 & 150,767 \\
\hline $\begin{array}{l}\text { Dichelostemma congestum (Sm.) } \\
\text { Kunth }\end{array}$ & 0,738 & 0,386 & 0,672 & 0,623 & 0,148 & 121,848 & 151,420 & 136,129 \\
\hline Encelia californica Nutt. & 0,151 & 0,807 & 0,731 & 0,731 & 0,328 & 154,299 & 66,895 & 143,383 \\
\hline Hemerocallis fulva (L.) L. & 0,088 & 0,776 & 0,899 & 0,375 & 0,290 & 151,678 & 75,878 & 172,690 \\
\hline Hypoxis hirsuta (L.) Coville & 0,152 & 0,905 & 0,898 & 0,420 & 0,252 & 182,896 & 42,368 & 149,609 \\
\hline Lilium columbianum Leichtlin & 0,099 & 0,753 & 0,823 & 0,769 & 0,503 & 149,599 & 76,515 & 162,032 \\
\hline Lilium pardalinum Kellogg & 0,215 & 0,829 & 0,530 & 0,739 & 0,330 & 80,201 & 105,392 & 165,351 \\
\hline Lilium parvum Kellogg & 0,066 & 0,794 & 0,757 & 0,329 & 0,308 & 118,234 & 89,940 & 174,407 \\
\hline Narcissus pseudonarcissus L. & 0,147 & 0,867 & 0,770 & 0,662 & 0,303 & 157,693 & 59,900 & 147,545 \\
\hline $\begin{array}{l}\text { Pyrrhopappus carolinianus (Walter) } \\
\text { DC. }\end{array}$ & 0,165 & 0,743 & 0,697 & 0,661 & 0,194 & 152,002 & 74,973 & 137,354 \\
\hline Tetraneuris scaposa (DC.) Greene & 0,136 & 0,924 & 0,829 & 0,553 & 0,348 & 160,820 & 52,653 & 154,816 \\
\hline
\end{tabular}

Pengenalan Objek Bunga dengan Ekstraksi Fitur Warna dan Bentuk Menggunakan Metode Morfologi dan Nä̈ve Bayes (Maulana Fansyuri) 


\begin{tabular}{|c|c|c|c|c|c|c|c|c|}
\hline Tragopogon dubius Scop. & 0,159 & 0,791 & 0,818 & 0,419 & 0,099 & 173,782 & 59,517 & 142,450 \\
\hline Tragopogon porrifolius L. & 0,787 & 0,421 & 0,667 & 0,639 & 0,099 & 124,866 & 138,895 & 149,959 \\
\hline Trillium erectum L. & 0,860 & 0,701 & 0,624 & 0,572 & 0,272 & 93,929 & 127,020 & 170,913 \\
\hline Tussilago farfara L. & 0,153 & 0,799 & 0,875 & 0,517 & 0,232 & 182,786 & 54,560 & 146,017 \\
\hline Wyethia angustifolia (DC.) Nutt. & 0,140 & 0,940 & 0,790 & 0,470 & 0,145 & 153,508 & 54,419 & 153,074 \\
\hline
\end{tabular}

Setelah nilai Mean dari setiap variabel didapat, selanjutnya menghitung standar deviasi dari setiap variable dengan menggunakan persamaan:

$$
\text { Ó }=\sqrt{\sum_{i=1}^{n} \frac{(\mathrm{xi}-\mu)^{2}}{2}}
$$

Hasil perhitungan standar deviasi menggunakan data latih terlihat pada tabel di bawah ini:

Tabel 3. Standar deviasi.

\begin{tabular}{lcccccccc}
\hline \multicolumn{1}{c}{ Standar Deviasi } & H & S & V & eccentricity & metric & Y & CB & CR \\
\hline Brodiaea elegans Hoover & 0,040 & 0,013 & 0,053 & 0,132 & 0,066 & 6,070 & 6,598 & 7,802 \\
\hline Calochortus kennedyi Porter & 0,061 & 0,024 & 0,251 & 0,157 & 0,085 & 45,180 & 19,948 & 12,257 \\
\hline Calochortus luteus Douglas ex & 0,000 & 0,010 & 0,028 & 0,107 & 0,114 & 5,321 & 2,754 & 0,560 \\
\hline Calochortus splendens Douglas ex & 0,009 & 0,112 & 0,077 & 0,141 & 0,107 & 22,635 & 4,995 & 3,342 \\
\hline $\begin{array}{l}\text { Dichelostemma congestum (Sm.) } \\
\text { Kunth }\end{array}$ & 0,005 & 0,118 & 0,136 & 0,210 & 0,045 & \multirow{2}{*}{11,715} & 13,529 & 2,999 \\
\hline Encelia californica Nutt. & 0,014 & 0,105 & 0,046 & 0,301 & 0,168 & 13,885 & 6,632 & 4,096 \\
\hline Hemerocallis fulva (L.) L. & 0,037 & 0,012 & 0,034 & 0,072 & 0,135 & 14,692 & 10,710 & 16,163 \\
\hline Hypoxis hirsuta (L.) Coville & 0,007 & 0,051 & 0,070 & 0,168 & 0,081 & 12,305 & 7,007 & 3,064 \\
\hline Lilium columbianum Leichtlin & 0,030 & 0,091 & 0,061 & 0,048 & 0,035 & 18,503 & 18,093 & 4,759 \\
\hline Lilium pardalinum Kellogg & 0,117 & 0,024 & 0,094 & 0,148 & 0,279 & 17,759 & 9,059 & 3,690 \\
\hline Lilium parvum Kellogg & 0,019 & 0,065 & 0,003 & 0,149 & 0,020 & 8,430 & 8,627 & 6,176 \\
\hline Narcissus pseudonarcissus L. & 0,001 & 0,058 & 0,037 & 0,006 & 0,050 & 7,889 & 0,804 & 0,257 \\
\hline $\begin{array}{l}\text { Pyrrhopappus carolinianus (Walter) } \\
\text { DC. }\end{array}$ & 0,016 & 0,143 & 0,113 & 0,197 & 0,106 & 26,256 & 3,513 & 5,422 \\
\hline Tetraneuris scaposa (DC.) Greene & 0,011 & 0,035 & 0,089 & 0,155 & 0,064 & 22,701 & 8,463 & 3,506 \\
\hline Tragopogon dubius Scop. & 0,010 & 0,028 & 0,055 & 0,019 & 0,022 & 8,580 & 5,107 & 4,645 \\
\hline Tragopogon porrifolius L. & 0,022 & 0,065 & 0,163 & 0,176 & 0,010 & 23,282 & 12,819 & 11,413 \\
\hline Trillium erectum L. & 0,078 & 0,133 & 0,187 & 0,201 & 0,111 & 30,778 & 10,417 & 8,446 \\
\hline Tussilago farfara L. & 0,003 & 0,028 & 0,065 & 0,139 & 0,209 & 12,878 & 8,251 & 1,863 \\
\hline Wyethia angustifolia (DC.) Nutt. & 0,022 & 0,002 & 0,083 & 0,159 & 0,037 & 9,588 & 5,243 & 10,891 \\
\hline
\end{tabular}

Selanjurnya menghitung densitas probabilitas dari setiap variabel menggunakan persamaan:

$$
p(x=v \mid c)=\frac{1}{\sqrt{2 \mu 0^{2}}} \exp ^{\frac{(\mathrm{x}-\mu)^{2}}{2 \hat{O}^{2}}}
$$

Hasil perhitungan densitas probabilitas menggunakan data latih dari setiap variabel terlihat pada tabel di bawah ini:

\begin{tabular}{|c|c|c|c|c|c|c|c|c|c|c|}
\hline Data Sample & $\begin{array}{l}\underset{\Xi}{\Xi} \\
\stackrel{\Xi}{\Xi} \\
\boldsymbol{I}^{\prime}\end{array}$ & 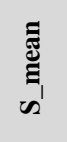 & $\begin{array}{l}\underset{\Xi}{\mathbb{E}} \\
\underset{\Xi}{\Xi} \\
>^{\prime}\end{array}$ & & $\stackrel{\Xi}{\Xi}$ & 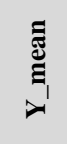 & 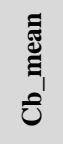 & 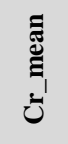 & & \\
\hline $\begin{array}{l}\text { Narcissus } \\
\text { pseudonarcissus L. }\end{array}$ & $\begin{array}{c}0,14 \\
78\end{array}$ & $\begin{array}{c}0,90 \\
10\end{array}$ & $\begin{array}{c}0,74 \\
87\end{array}$ & $\begin{array}{c}0,66 \\
61\end{array}$ & $\begin{array}{c}0,27 \\
46\end{array}$ & $\begin{array}{l}153, \\
1386\end{array}$ & $\begin{array}{l}59,4 \\
358\end{array}$ & $\begin{array}{l}147, \\
3963\end{array}$ & & \\
\hline \multicolumn{11}{|l|}{ Densitas Probabiltas } \\
\hline Brodiaea elegans & $2,6 \mathrm{E}$ & $1,2 \mathrm{E}$ & $1,7 \mathrm{E}$ & $6,0 \mathrm{E}$ & $1,1 \mathrm{E}$ & $5,3 \mathrm{E}$ & $5,6 \mathrm{E}$ & $1,3 \mathrm{E}$ & $0,0 \mathrm{E}+$ & Brodiaea elegans \\
\hline Hoover & -48 & -262 & +00 & -03 & +00 & -05 & -48 & -01 & 00 & Hoover \\
\hline Calochortus kennedyi & $1,2 \mathrm{E}$ & $1,6 \mathrm{E}$ & $7,7 \mathrm{E}$ & $4,1 \mathrm{E}$ & $1,9 \mathrm{E}$ & $2,9 \mathrm{E}$ & $2,5 \mathrm{E}$ & $7,8 \mathrm{E}$ & $6,3 \mathrm{E}-$ & Calochortus kennedyi \\
\hline Porter & +00 & -01 & -01 & -01 & -08 & -02 & -02 & -03 & 15 & Porter \\
\hline Calochortus luteus & $8,8 \mathrm{E}$ & $2,6 \mathrm{E}$ & $1,3 \mathrm{E}$ & $2,7 \mathrm{E}$ & $1,9 \mathrm{E}$ & $3,2 \mathrm{E}$ & $3,8 \mathrm{E}$ & $2,3 \mathrm{E}$ & $0,0 \mathrm{E}+$ & Calochortus luteus \\
\hline Douglas ex & -113 & -04 & -50 & -02 & -04 & -46 & -37 & -93 & 00 & Douglas ex \\
\hline Calochortus splendens & $0,0 \mathrm{E}$ & $6,3 \mathrm{E}$ & $1,4 \mathrm{E}$ & $3,3 \mathrm{E}$ & $1,3 \mathrm{E}$ & $6,3 \mathrm{E}$ & $2,6 \mathrm{E}$ & $1,3 \mathrm{E}$ & $0,0 \mathrm{E}+$ & Calochortus splendens \\
\hline Douglas ex & +00 & -05 & +00 & -02 & -05 & -02 & -71 & -01 & 00 & Douglas ex \\
\hline
\end{tabular}

Tabel 4. Densitas probabilitas.

JURNAL SISTEM DAN INFORMATIKA Vol. 15, No. 1, November 2020. 


\begin{tabular}{|c|c|c|c|c|c|c|c|c|c|c|}
\hline $\begin{array}{l}\text { Dichelostemma } \\
\text { congestum (Sm.) } \\
\text { Kunth }\end{array}$ & $\begin{array}{l}0,0 \mathrm{E} \\
+00\end{array}$ & $\begin{array}{l}7,9 \mathrm{E} \\
-05\end{array}$ & $\begin{array}{l}9,2 \mathrm{E} \\
-01\end{array}$ & $\begin{array}{l}8,5 \mathrm{E} \\
-01\end{array}$ & $\begin{array}{c}3,4 \mathrm{E} \\
-02\end{array}$ & $\begin{array}{c}3,3 \mathrm{E} \\
-03\end{array}$ & $\begin{array}{l}1,0 \mathrm{E} \\
-11\end{array}$ & $\begin{array}{l}2,0 \mathrm{E} \\
-04\end{array}$ & $\begin{array}{c}0,0 \mathrm{E}+ \\
00\end{array}$ & $\begin{array}{l}\text { Dichelostemma } \\
\text { congestum (Sm.) } \\
\text { Kunth }\end{array}$ \\
\hline $\begin{array}{l}\text { Encelia californica } \\
\text { Nutt. }\end{array}$ & $\begin{array}{l}3,3 \mathrm{E} \\
+00\end{array}$ & $\begin{array}{l}8,3 \mathrm{E} \\
-01\end{array}$ & $\begin{array}{l}1,7 \mathrm{E} \\
+00\end{array}$ & $\begin{array}{l}7,1 \mathrm{E} \\
-01\end{array}$ & $\begin{array}{l}9,2 \mathrm{E} \\
-01\end{array}$ & $\begin{array}{l}1,1 \mathrm{E} \\
-01\end{array}$ & $\begin{array}{l}8,2 \mathrm{E} \\
-02\end{array}$ & $\begin{array}{l}1,2 \mathrm{E} \\
-01\end{array}$ & $\begin{array}{l}3,3 \mathrm{E}- \\
03\end{array}$ & $\begin{array}{l}\text { Encelia californica } \\
\text { Nutt. }\end{array}$ \\
\hline $\begin{array}{l}\text { Hemerocallis fulva (L.) } \\
\text { L. }\end{array}$ & $\begin{array}{c}5,7 \mathrm{E} \\
-01 \\
\end{array}$ & $\begin{array}{l}3,1 \mathrm{E} \\
-22 \\
\end{array}$ & $\begin{array}{l}1,3 \mathrm{E} \\
-04 \\
\end{array}$ & $\begin{array}{c}3,7 \mathrm{E} \\
-04 \\
\end{array}$ & $\begin{array}{l}1,1 \mathrm{E} \\
+00 \\
\end{array}$ & $\begin{array}{l}1,0 \mathrm{E} \\
-01 \\
\end{array}$ & $\begin{array}{c}3,8 \mathrm{E} \\
-02 \\
\end{array}$ & $\begin{array}{c}2,9 \mathrm{E} \\
-02 \\
\end{array}$ & $\begin{array}{c}1,0 \mathrm{E}- \\
33\end{array}$ & $\begin{array}{l}\text { Hemerocallis fulva (L.) } \\
\text { L. }\end{array}$ \\
\hline $\begin{array}{l}\text { Hypoxis hirsuta (L.) } \\
\text { Coville }\end{array}$ & $\begin{array}{l}4,1 \mathrm{E} \\
+00\end{array}$ & $\begin{array}{l}1,8 \mathrm{E} \\
+00\end{array}$ & $\begin{array}{c}1,6 \mathrm{E} \\
-01\end{array}$ & $\begin{array}{c}3,3 \mathrm{E} \\
-01\end{array}$ & $\begin{array}{l}1,3 \mathrm{E} \\
+00\end{array}$ & $\begin{array}{l}6,1 \mathrm{E} \\
-03\end{array}$ & $\begin{array}{l}7,8 \mathrm{E} \\
-03\end{array}$ & $\begin{array}{l}1,8 \mathrm{E} \\
-01\end{array}$ & $\begin{array}{c}4,2 \mathrm{E}- \\
06\end{array}$ & $\begin{array}{l}\text { Hypoxis hirsuta (L.) } \\
\text { Coville }\end{array}$ \\
\hline $\begin{array}{l}\text { Lilium columbianum } \\
\text { Leichtlin }\end{array}$ & $\begin{array}{c}5,9 \mathrm{E} \\
-01 \\
\end{array}$ & $\begin{array}{c}3,5 \mathrm{E} \\
-01\end{array}$ & $\begin{array}{l}7,6 \mathrm{E} \\
-01 \\
\end{array}$ & $\begin{array}{c}1,8 \mathrm{E} \\
-01\end{array}$ & $\begin{array}{l}1,5 \mathrm{E} \\
-09\end{array}$ & $\begin{array}{l}9,1 \mathrm{E} \\
-02\end{array}$ & $\begin{array}{l}6,0 \mathrm{E} \\
-02\end{array}$ & $\begin{array}{l}1,6 \mathrm{E} \\
-03\end{array}$ & $\begin{array}{c}3,8 \mathrm{E}- \\
16\end{array}$ & $\begin{array}{l}\text { Lilium columbianum } \\
\text { Leichtlin }\end{array}$ \\
\hline $\begin{array}{l}\text { Lilium pardalinum } \\
\text { Kellogg }\end{array}$ & $\begin{array}{c}9,9 \mathrm{E} \\
-01 \\
\end{array}$ & $\begin{array}{l}2,6 \mathrm{E} \\
-02 \\
\end{array}$ & $\begin{array}{l}8,4 \mathrm{E} \\
-02 \\
\end{array}$ & $\begin{array}{c}9,2 \mathrm{E} \\
-01 \\
\end{array}$ & $\begin{array}{c}7,4 \mathrm{E} \\
-01 \\
\end{array}$ & $\begin{array}{c}2,1 \mathrm{E} \\
-05 \\
\end{array}$ & $\begin{array}{c}3,4 \mathrm{E} \\
-07 \\
\end{array}$ & $\begin{array}{l}1,5 \mathrm{E} \\
-06 \\
\end{array}$ & $\begin{array}{c}1,6 \mathrm{E}- \\
20 \\
\end{array}$ & $\begin{array}{l}\text { Lilium pardalinum } \\
\text { Kellogg }\end{array}$ \\
\hline $\begin{array}{l}\text { Lilium parvum } \\
\text { Kellogg }\end{array}$ & $\begin{array}{c}3,2 \mathrm{E} \\
-04\end{array}$ & $\begin{array}{l}4,1 \mathrm{E} \\
-01\end{array}$ & $\begin{array}{l}9,6 \mathrm{E} \\
-02\end{array}$ & $\begin{array}{l}8,1 \mathrm{E} \\
-02\end{array}$ & $\begin{array}{c}6,8 \mathrm{E} \\
-01\end{array}$ & $\begin{array}{l}2,6 \mathrm{E} \\
-05\end{array}$ & $\begin{array}{l}2,6 \mathrm{E} \\
-04\end{array}$ & $\begin{array}{l}1,1 \mathrm{E} \\
-05\end{array}$ & $\begin{array}{l}5,4 \mathrm{E}- \\
20\end{array}$ & $\begin{array}{l}\text { Lilium parvum } \\
\text { Kellogg }\end{array}$ \\
\hline $\begin{array}{l}\text { Narcissus } \\
\text { pseudonarcissus L. }\end{array}$ & $\begin{array}{l}1,1 \mathrm{E} \\
+01 \\
\end{array}$ & $\begin{array}{l}1,4 \mathrm{E} \\
+00 \\
\end{array}$ & $\begin{array}{l}1,8 \mathrm{E} \\
+00 \\
\end{array}$ & $\begin{array}{l}4,2 \mathrm{E} \\
+00 \\
\end{array}$ & $\begin{array}{l}1,5 \mathrm{E} \\
+00 \\
\end{array}$ & $\begin{array}{l}1,2 \mathrm{E} \\
-01 \\
\end{array}$ & $\begin{array}{c}3,8 \mathrm{E} \\
-01 \\
\end{array}$ & $\begin{array}{c}6,7 \mathrm{E} \\
-01 \\
\end{array}$ & $\begin{array}{c}5,4 \mathrm{E}+ \\
00\end{array}$ & $\begin{array}{l}\text { Narcissus } \\
\text { pseudonarcissus L. }\end{array}$ \\
\hline $\begin{array}{l}\text { Pyrrhopappus } \\
\text { carolinianus (Walter) } \\
\text { DC. }\end{array}$ & $\begin{array}{l}1,8 \mathrm{E} \\
+00\end{array}$ & $\begin{array}{l}5,8 \mathrm{E} \\
-01\end{array}$ & $\begin{array}{l}1,1 \mathrm{E} \\
+00\end{array}$ & $\begin{array}{l}9,0 \mathrm{E} \\
-01\end{array}$ & $\begin{array}{l}9,2 \mathrm{E} \\
-01\end{array}$ & $\begin{array}{l}7,8 \mathrm{E} \\
-02\end{array}$ & $\begin{array}{l}1,2 \mathrm{E} \\
-05\end{array}$ & $\begin{array}{l}3,1 \mathrm{E} \\
-02\end{array}$ & $\begin{array}{l}2,6 \mathrm{E}- \\
08\end{array}$ & $\begin{array}{l}\text { Pyrrhopappus } \\
\text { carolinianus (Walter) } \\
\text { DC. }\end{array}$ \\
\hline $\begin{array}{l}\text { Tetraneuris scaposa } \\
\text { (DC.) Greene }\end{array}$ & $\begin{array}{l}2,1 \mathrm{E} \\
+00\end{array}$ & $\begin{array}{l}1,7 \mathrm{E} \\
+00\end{array}$ & $\begin{array}{c}8,9 \mathrm{E} \\
-01 \\
\end{array}$ & $\begin{array}{c}7,8 \mathrm{E} \\
-01 \\
\end{array}$ & $\begin{array}{c}8,1 \mathrm{E} \\
-01 \\
\end{array}$ & $\begin{array}{c}7,9 \mathrm{E} \\
-02 \\
\end{array}$ & $\begin{array}{c}9,9 \mathrm{E} \\
-02 \\
\end{array}$ & $\begin{array}{c}2,3 \mathrm{E} \\
-02 \\
\end{array}$ & $\begin{array}{c}3,7 \mathrm{E}- \\
04\end{array}$ & $\begin{array}{l}\text { Tetraneuris scaposa } \\
\text { (DC.) Greene }\end{array}$ \\
\hline $\begin{array}{l}\text { Tragopogon dubius } \\
\text { Scop. }\end{array}$ & $\begin{array}{l}2,1 \mathrm{E} \\
+00\end{array}$ & $\begin{array}{l}1,1 \mathrm{E} \\
-03\end{array}$ & $\begin{array}{l}7,8 \mathrm{E} \\
-01 \\
\end{array}$ & $\begin{array}{c}6,7 \mathrm{E} \\
-36 \\
\end{array}$ & $\begin{array}{l}1,3 \mathrm{E} \\
-13 \\
\end{array}$ & $\begin{array}{c}7,5 \mathrm{E} \\
-03 \\
\end{array}$ & $\begin{array}{l}1,8 \mathrm{E} \\
-01 \\
\end{array}$ & $\begin{array}{c}1,1 \mathrm{E} \\
-01 \\
\end{array}$ & $\begin{array}{c}2,1 \mathrm{E}- \\
55\end{array}$ & $\begin{array}{l}\text { Tragopogon dubius } \\
\text { Scop. }\end{array}$ \\
\hline $\begin{array}{l}\text { Tragopogon porrifolius } \\
\text { L. }\end{array}$ & $\begin{array}{l}1,3 \mathrm{E} \\
-178\end{array}$ & $\begin{array}{l}2,3 \mathrm{E} \\
-12\end{array}$ & $\begin{array}{c}8,7 \mathrm{E} \\
-01\end{array}$ & $\begin{array}{l}9,4 \mathrm{E} \\
-01\end{array}$ & $\begin{array}{l}3,4 \mathrm{E} \\
-70\end{array}$ & $\begin{array}{l}4,0 \mathrm{E} \\
-02\end{array}$ & $\begin{array}{l}5,1 \mathrm{E} \\
-10\end{array}$ & $\begin{array}{l}1,2 \mathrm{E} \\
-01\end{array}$ & $\begin{array}{l}1,9 \mathrm{E}- \\
271\end{array}$ & $\begin{array}{l}\text { Tragopogon porrifolius } \\
\text { L. }\end{array}$ \\
\hline Trillium erectum L. & $\begin{array}{l}1,0 \mathrm{E} \\
-18 \\
\end{array}$ & $\begin{array}{l}3,5 \mathrm{E} \\
-01 \\
\end{array}$ & $\begin{array}{c}7,4 \mathrm{E} \\
-01 \\
\end{array}$ & $\begin{array}{c}8,0 \mathrm{E} \\
-01 \\
\end{array}$ & $\begin{array}{l}1,2 \mathrm{E} \\
+00 \\
\end{array}$ & $\begin{array}{l}1,1 \mathrm{E} \\
-02 \\
\end{array}$ & $\begin{array}{l}8,9 \mathrm{E} \\
-11 \\
\end{array}$ & $\begin{array}{c}2,8 \mathrm{E} \\
-03 \\
\end{array}$ & $\begin{array}{c}7,4 \mathrm{E}- \\
34\end{array}$ & Trillium erectum L. \\
\hline Tussilago farfara $\mathrm{L}$. & $\begin{array}{l}2,0 \mathrm{E} \\
+00\end{array}$ & $\begin{array}{l}2,6 \mathrm{E} \\
-03\end{array}$ & $\begin{array}{c}2,3 \mathrm{E} \\
-01 \\
\end{array}$ & $\begin{array}{c}6,0 \mathrm{E} \\
-01\end{array}$ & $\begin{array}{c}8,6 \mathrm{E} \\
-01\end{array}$ & $\begin{array}{l}7,9 \mathrm{E} \\
-03\end{array}$ & $\begin{array}{l}1,2 \mathrm{E} \\
-01\end{array}$ & $\begin{array}{c}2,2 \mathrm{E} \\
-01\end{array}$ & $\begin{array}{c}1,3 \mathrm{E}- \\
07\end{array}$ & Tussilago farfara L. \\
\hline $\begin{array}{l}\text { Wyethia angustifolia } \\
\text { (DC.) Nutt. }\end{array}$ & $\begin{array}{l}2,5 \mathrm{E} \\
+00\end{array}$ & $\begin{array}{l}1,8 \mathrm{E} \\
-64\end{array}$ & $\begin{array}{l}1,2 \mathrm{E} \\
+00\end{array}$ & $\begin{array}{c}4,7 \mathrm{E} \\
-01\end{array}$ & $\begin{array}{l}4,6 \mathrm{E} \\
-03\end{array}$ & $\begin{array}{l}1,3 \mathrm{E} \\
-01\end{array}$ & $\begin{array}{l}1,1 \mathrm{E} \\
-01\end{array}$ & $\begin{array}{l}1,1 \mathrm{E} \\
-01\end{array}$ & $\begin{array}{c}1,7 \mathrm{E}- \\
69\end{array}$ & $\begin{array}{l}\text { Wyethia angustifolia } \\
\text { (DC.) Nutt. }\end{array}$ \\
\hline & & & & & & \multicolumn{3}{|c|}{ Probabilitas Terbesar } & $\begin{array}{c}5,3508 \\
\mathrm{E}+00\end{array}$ & $\begin{array}{c}\text { Narcissus } \\
\text { pseudonarcissus L. }\end{array}$ \\
\hline
\end{tabular}

Probabilitas yang dihasilkan dari perhitungan densitas probabilitas dan memiliki nilai paling besar akan menunjukkan spesies dari citra tersebut, dari nilai probabilitas dari tabel di atas, nilai probabilitas terbesar ditunjukkan oleh densitas probabilitas dari spesies "Narcissus pseudonarcissus L" dan hasil ini akurat dengan data sample yang digunakan yaitu data tes dari spesies "Narcissus pseudonarcissus L".

\subsection{Pengujian Akurasi}

Keakuratan hasil klasifikasi dapat diukur dengan menggunakan Confusion Matrix. Confusion Matrix adalah media yang berguna untuk menganalisis seberapa baik classifier dapat mengenali tupel dari kelas yang berbeda [10]. Misalkan terdapat dua kelas, maka akan diistilahkan sebagai tupel positif dan tupel negatif. True positive mengacu pada tupel positif yang diberi label dengan tepat oleh classifier, sementara true negative adalah tupel positif yang diberi label dengan tepat oleh classifier. False positive adalah tupel negatif yang diberi label tidak tepat, false negative adalah tupel positif yang diberi label dengan tidak tepat. Secara umum istilah ini berguna untuk menganalisis kemampuan classifier dan diringkas seperti tabel berikut.

Tabel 5. Model Confusion Matrix

\begin{tabular}{lll}
\hline & $\mathrm{C} 1$ & $\mathrm{C} 2$ \\
\hline $\mathrm{C}$ & True Positive & False Negative \\
\hline $\mathrm{C}$ & False Positive & True Negative \\
\hline
\end{tabular}

Dalam analisis pengenalan citra bunga ini variabel yang dihasilkan lebih dari 2 kelas, maka indikator untuk mendapatkan akurasi sebuah algoritma adalah menggunakan precission, recall, accuracy, dan specificity. Untuk penjelasan masing-masing indikator adalah sebagai berikut:

\subsubsection{Accuracy}

Akurasi merupakan nilai persentase dari total seluru data yang diidentifikasi dan dinilai benar. Persamaan untuk menghitung akurasi adalah:

$$
\text { Akurasi = True Positif } / \text { Total Dataset }
$$




$$
\text { Accuration } \frac{\text { True Positive }}{\sum \text { Dataset }} \times 100 \%
$$

Di mana TP (True Positive) merupakan sebuah Kelas yang mampu diprediksi dengan benar dan tepat. Fungsi True Positive digunakan untuk menghitung nilai akurasi.

\subsubsection{Presisi}

Presisi merupakan data yang diambil berdasarkan informasi yang salah atau kurang. Persamaan untuk menghitung akurasi adalah:

$$
\text { Precision = True Positif } /(\text { True Positif + False Positif })
$$

Setelah mendapatkan nilai precision dari masing-masing kelas, selanjutnya menghitung nilai precision dari data semua kelas, menggunakan persamaan sebagai berikut:

\subsubsection{Recall}

$$
\text { All Precision } \frac{P 1+\cdots+P n}{\sum \text { Variable }} \times 100 \%
$$
recall adalah:

Recall merupakan data yang tidak mampu diprediksi dengan benar. Persamaan untuk menghitung

$$
\text { Recall }=\text { True Positif } /(\text { True Positif }+ \text { False Negative })
$$

Setelah mendapatkan nilai recall dari masing-masing kelas, selanjutnya menghitung nilai recall dari data semua kelas, menggunakan persamaan sebagai berikut:

\subsubsection{Specificity}

$$
\text { All Recall } \frac{R 1+\cdots+R n}{\sum \text { Variable }} \times 100 \%
$$

Specificity merupakan sebuah kelas yang mampu diprediksi dengan salah atau tidak tepat. Persamaan untuk menghitung specificity adalah:

$$
\text { Specificity }=\text { True Negative (True Negative }+ \text { False Positive })
$$

\begin{tabular}{|c|c|c|c|c|c|c|c|c|c|c|c|c|c|c|c|c|c|c|c|}
\hline & 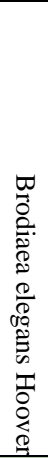 & 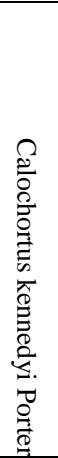 & 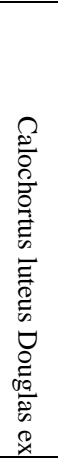 & 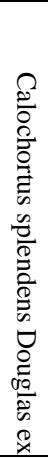 & 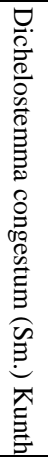 & 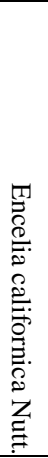 & 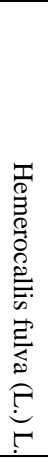 & 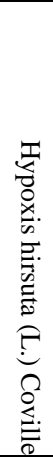 & 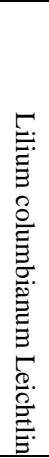 & 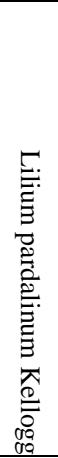 & 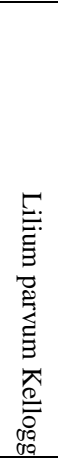 & $\begin{array}{l}Z \\
0 \\
0 \\
0 \\
5 \\
0 \\
0 \\
0 \\
0 \\
0 \\
0 \\
0 \\
0 \\
0 \\
0 \\
0 \\
0 \\
0 \\
0 \\
0 \\
0 \\
0 \\
0\end{array}$ & 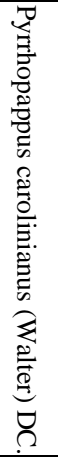 & 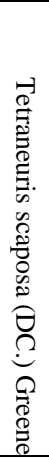 & 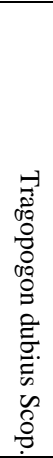 & 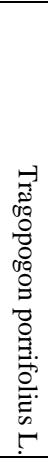 & 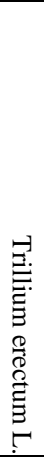 & 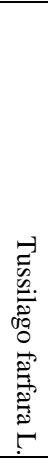 & 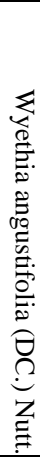 \\
\hline Brodiaea elegans Hoover & 9 & 0 & 0 & 0 & 0 & 0 & 0 & 0 & 0 & 0 & 0 & 0 & 0 & 0 & 0 & 0 & 0 & 0 & 0 \\
\hline Calochortus kennedyi Porter & 0 & 12 & 0 & 0 & 0 & 0 & 0 & 0 & 1 & 1 & 1 & 1 & 0 & 0 & 0 & 0 & 0 & 0 & 0 \\
\hline Calochortus luteus Douglas ex & 0 & 0 & 10 & 0 & 0 & 0 & 0 & 0 & 0 & 0 & 0 & 0 & 0 & 0 & 0 & 0 & 0 & 0 & 0 \\
\hline Calochortus splendens Douglas ex & 0 & 0 & 0 & 9 & 0 & 0 & 0 & 0 & 0 & 0 & 0 & 0 & 0 & 0 & 0 & 0 & 0 & 0 & 0 \\
\hline Dichelostemma congestum (Sm.) Kunth & 2 & 0 & 0 & 1 & 11 & 0 & 0 & 0 & 0 & 0 & 0 & 0 & 0 & 0 & 0 & 0 & 0 & 0 & 0 \\
\hline Encelia californica Nutt. & 0 & 0 & 1 & 0 & 0 & 9 & 0 & 2 & 0 & 0 & 0 & 3 & 0 & 0 & 3 & 0 & 0 & 0 & 0 \\
\hline Hemerocallis fulva (L.) L. & 0 & 0 & 0 & 0 & 0 & 2 & 7 & 0 & 0 & 2 & 3 & 1 & 0 & 0 & 0 & 0 & 0 & 0 & 0 \\
\hline Hypoxis hirsuta (L.) Coville & 0 & 0 & 0 & 0 & 0 & 0 & 0 & 8 & 0 & 0 & 0 & 0 & 3 & 1 & 0 & 0 & 0 & 1 & 2 \\
\hline Lilium columbianum Leichtlin & 0 & 0 & 0 & 0 & 0 & 0 & 0 & 0 & 7 & 1 & 0 & 0 & 0 & 0 & 0 & 0 & 0 & 0 & 0 \\
\hline
\end{tabular}

Setelah mendapatkan nilai specificity dari masing-masing kelas, selanjutnya menghitung nilai specificity dari data semua kelas, menggunakan persamaan sebagai berikut:

$$
\text { All Specificity } \frac{S 1+\cdots+S n}{\sum \text { Variable }} \times 100 \%
$$

Tabel 6. Hasil statistik data keseluruhan. 


\begin{tabular}{lcccccccccccccccccccc}
\hline Lilium pardalinum Kellogg & 0 & 0 & 0 & 0 & 0 & 0 & 1 & 0 & 0 & 8 & 2 & 0 & 0 & 0 & 0 & 0 & 3 & 0 & 0 \\
\hline Lilium parvum Kellogg & 0 & 0 & 0 & 0 & 0 & 0 & 0 & 0 & 0 & 0 & 6 & 0 & 0 & 0 & 0 & 0 & 0 & 0 & 0 \\
\hline Narcissus pseudonarcissus L. & 0 & 0 & 0 & 0 & 0 & 0 & 0 & 0 & 0 & 0 & 0 & 6 & 0 & 0 & 0 & 0 & 0 & 0 & 0 \\
\hline Pyrrhopappus carolinianus (Walter) DC. & 0 & 0 & 0 & 0 & 0 & 1 & 1 & 2 & 0 & 0 & 0 & 1 & 7 & 1 & 2 & 0 & 0 & 0 & 0 \\
\hline Tetraneuris scaposa (DC.) Greene & 0 & 0 & 0 & 0 & 0 & 0 & 0 & 0 & 4 & 0 & 0 & 0 & 2 & 10 & 0 & 0 & 0 & 0 & 2 \\
\hline Tragopogon dubius Scop. & 0 & 0 & 0 & 0 & 0 & 0 & 0 & 0 & 0 & 0 & 0 & 0 & 0 & 0 & 7 & 0 & 0 & 0 & 0 \\
\hline Tragopogon porrifolius L. & 0 & 0 & 0 & 0 & 0 & 0 & 0 & 0 & 0 & 0 & 0 & 0 & 0 & 0 & 0 & 9 & 0 & 0 & 0 \\
\hline Trillium erectum L. & 1 & 0 & 0 & 2 & 1 & 0 & 3 & 0 & 0 & 0 & 0 & 0 & 0 & 0 & 0 & 3 & 9 & 0 & 0 \\
\hline Tussilago farfara L. & 0 & 0 & 1 & 0 & 0 & 0 & 0 & 0 & 0 & 0 & 0 & 0 & 0 & 0 & 0 & 0 & 0 & 10 & 0 \\
\hline Wyethia angustifolia (DC.) Nutt. & 0 & 0 & 0 & 0 & 0 & 0 & 0 & 0 & 0 & 0 & 0 & 0 & 0 & 0 & 0 & 0 & 0 & 1 & 8 \\
\hline
\end{tabular}

Tabel 7. Hasil eksperimen.

\begin{tabular}{|c|c|}
\hline Indikator & Persentase \\
\hline Akurasi $=$ TP $/$ Total Dataset & $71,1 \%$ \\
\hline Precision = TP $/(\mathrm{TP}+\mathrm{FP})$ & $71,1 \%$ \\
\hline Recall = TP/(TP+FN $)$ & $77,8 \%$ \\
\hline All Specificity = (Jumlah Specificity / Jumlah Kelas $)$ & $98,4 \%$ \\
\hline
\end{tabular}

Dari hasil uji coba menggunakan 228 gambar bunga dari data tes, dengan menggunakan metode Confusion Matrix data disimpulkan bahwa tingkat akurasi dengan menggunakan metode Naïve Bayes dari data ekstraksi warna dan bentuk dari citra bunga sebesar 71,1\%.

\subsection{Area Under Curve}

Area Under Curve atau biasa disingkat AUC digunakan untuk mengukur perbedaan performansi dalam sebuah algoritma. Untuk klasifikasi data mining, nilai AUC dapat dibagi menjadi beberapa kelompok [12]:
a. $0.90-1.00=$ Klasifikasi sangat baik
b. $0.80-0.90=$ Klasifikasi baik
c. $0.70-0.80=$ Klasifikasi cukup
d. $0.60-0.70=$ Klasifikasi buruk
e. $0.50-0.60=$ Klasifikasi salah

Pada penelitian ini untuk menghitung nilai AUC dengan menggunakan lebih dari dua kelas maka persamaan yang digunakan adalah:

$$
A U C=\frac{\text { Recall }+ \text { Specificity }}{2}
$$

Maka dalam perhitungan yang dilakukan menggunakan citra bunga dari dataset maka nilai AUC adalah $(77,8 \%+98,4 \%) / 2=88 \%$. Dari hasil ini didapati bahwa analisis citra bunga menggunakan hasil Ekstraksi warna dan bentuk dengan metode Naïve Bayes termasuk dalam algoritma klasifikasi yang baik, sehingga data hasil klasifikasi Naïve Bayes sesuai dengan data citra sebenarnya.

\section{Kesimpulan}

Dari hasil penelitian yang dilakukan pada citra bunga berdasarkan warna dan bentuk menggunakan metode Naïve Bayes dapat diambil kesimpulan bahwa metode ini termasuk dalam algoritma yang baik untuk diaplikasikan pada klasifikasi citra bunga berdasarkan warna dan bentuk dengan nilai AUC sebesar $88 \%$ dan metode ini menghasilkan nilai akurasi sebesar $71,1 \%$, sehingga pengenalan objek bunga menggunakan data hasil ekstraksi warna dan bentuk serta menggunakan metode klasifikasi Naïve Bayes sesuai dengan data citra sebenarnya

\section{Ucapan Terima Kasih}

Peneliti mengucapkan terima kasih kepada LPPM Unpam dan Direktorat Riset dan Pengabdian Masyarakat Direktorat Jenderal Penguatan Riset dan Pengembangan Kementerian Riset dan Teknologi/Badan Riset dan Inovasi Nasional Nomor:0105/D5/KP/LPPM/UNPAM/IV/2020 yang telah mendukung penelitian kami ini.

\section{Daftar Pustaka}

[1] dkk Nur Ridha Apriyanti, "Algortima K-Means Clustering Dalam Pengolahan Citra Digital Landsat,” Ilmu Komput., vol. 02, no. Clustering K-Measn, pp. 1-13, 2015.

[2] P. Rosyani, "Deteksi Citra Bunga Menggunakan Analisis Segmentasi Fuzzy C-Means dan Otsu 
Threshold," vol. 20, no. 1, 2020.

[3] P. Rosyani, "Pengenalan Wajah Menggunakan Metode Principal Component Analysis (PCA) dan Canberra Distance," J. Inform. Univ. Pamulang, vol. 2, no. 2, p. 118, 2017.

[4] Atina, "Segmentasi Citra Paru Menggunakan Metode k-Means Clustering," Segmentasi Citra Paru Menggunakan Metod. k-Means Clust., vol. 3, no. 2, pp. 57-65, 2017.

[5] P. Rosyani, M. Taufik, A. A. Waskita, and D. H. Apriyanti, "Comparison of color model for flower recognition,” 2018 3rd Int. Conf. Inf. Technol. Inf. Syst. Electr. Eng., pp. 10-14, 2019.

[6] D. H. Apriyanti, A. M. Arymurthy, and L. T. Handoko, "Identification of Orchid Species Using," pp. 53-57, 2013.

[7] I. Setiawan, W. Dewanta, H. A. Nugroho, and H. Supriyono, "Pengolah Citra Dengan Metode Thresholding Dengan Matlab R2014A," J. Media Infotama, vol. 15, no. 2, pp. 65-70, 2019.

[8] D. Rohpandi, A. Sugiharto, and M. Y. S. Jati, "Klasifikasi Citra Digital Berbasis Ekstraksi Ciri Berdasarkan Tekstur Menggunakan GLCM Dengan Algoritma K-Nearest Neighbor,” J. Inform., vol. 3, no. 2, pp. 79-86, 2017.

[9] A. A. Arifiyanti, R. M. Pradana, and I. F. Novian, "Klasifikasi Produk Retur dengan Algoritma Pohon Keputusan C4.5," J. IPTEK, vol. 22, no. 1, p. 79, 2018.

[10] E. Pudjiarti, "Prediksi Spam Email Menggunakan Metode Support Vector Machine Dan Particle Swarm Optimization," J. Pilar Nusa Mandiri, vol. 12, no. 2, pp. 171-181, 2016. 